УДК 821.112.2 Д- 309

\title{
Зоя Кучер
}

\section{ПРОБЛЕМА ВИКОРИСТАННЯ ПЕРЕКЛАДАЦЬКИХ ТРАНСФОРМАЦЙ У ПРОЦЕСІ ПЕРЕКЛАДУ ХУДОЖНЬОГО ТЕКСТУ}

У запропонованій статті досліджено особливості використання граматичних трансформацій, а саме прийоми замін частин мови в процесі перекладу збірки швейцарського письменника Ф. Дюренмата «Лабіринт», виконаного відомим українським перекладачем О. Логвиненком. Розглядаємо одну з найважливіших проблем художнього перекладу - проблему точності, правильності та адекватності, вирішити яку неможсливо без використання різнотипових прийомів перекладацьких трансформацій. Аналізуемо стан вивчення проблеми перекладацьких трансформачій у сучасному вітчизняному перекладознавстві. На основі фактичного матеріалу трунтовно проаналізовано особливості використання граматичних замін. Основними мотивами застосування замін частин мови є, переважно прагнення подолати розбіжності між системою та нормою мови оригіналу і перекладу, уникнути буквалізмів, неприродності деяких зворотів та використовувати граматичні конструкиії, які відповідають нормі української мови.

Ключові слова: перекладачька трансформація, граматична заміна, заміна частин мови, адекватний переклад, мотиви використання перекладачьких трансформацій.

Вступ. На початку XXI століття проблема художнього перекладу все частіше стає предметом досліджень у сучасному вітчизняному перекладознавстві. До кола важливих питань наукових розвідок останніх часів потрапляють літературознавчі аспекти художнього перекладу (Лановик, 2006), актуальні теоретичні концепції та моделі поетичного перекладу (Коломієць, 2004), а також крос-культурні та загальні перекладознавчі проблеми, а саме теорія інтерпретації (Демецька, 2006). Актуальними стають праці, де художній переклад розглядають як важливий чинник націєтворення (Стріха, 2006, Зорівчак, 2007) та як культурний феномен (Бевз, 2010). Українська дослідниця Т. Андрієнко (2016) досліджує стратегії й тактики перекладу художнього тексту в когнітивно-дискурсивному аспекті. Необхідно зауважити, що об'єктом наукових досліджень останніх часів стають не лише окремі проблеми художнього перекладу, а й постать самого перекладача як поліфункціонального, культурного посередника, діяльність якого розглядаємо в широкому соціокультурному та особистісному контексті (Іваницька, 2015), а 
також творчість як невід’ємна складова перекладацької діяльності, що характеризує як іiї процесуальний, так і продуктивний аспекти (Ребрій, 2012).

Теоретичне підгрунтя. Актуальність запропонованої статті пов'язана зі станом сучасних вітчизняних досліджень у галузі перекладознавства, що вказує на значний інтерес до проблеми художнього перекладу як особливого виду перекладацької діяльності, а саме, до вивчення способів та прийомів адекватного відтворення оригінального тексту.

Однією з важливих проблем художнього перекладу є проблема точності, правильності та адекватності. Як відомо, системи мови оригіналу та перекладу можуть суттєво відрізнятися, що призводить до неможливості відтворення лексичних, граматичних, стилістичних, а інколи й змістових особливостей оригіналу. Необхідно наголосити, що для перекладача художнього твору надважливим завданням є наближення за інтенсивністю та якістю до ефекту, що його відчував читач оригінального тексту. Український дослідник О. Чередниченко в цьому контексті зазначає, що «для адекватного відтворення художнього цілого перекладач має зіставляти, бодай уявно, можливі естетичні реакції на нього і читачів оригіналу, і читачів перекладу, і робити все можливе, щоб ці реакції були бодай приблизно однаковими» (Чередниченко, 2008, с. 21). Отже, перекладач має розуміти внутрішню систему мови оригіналу та структуру тексту цією мовою і побудувати такий текстуальний простір, що впливатиме на читача тексту перекладу аналогічно, причому в усіх аспектах, змістовому, структурному та функціональному, а це означає - створювати емоційний вплив, до якого прагне текст-джерело.

У цьому зв'язку важливим $є$ грунтовний аналіз прийомів перекладацьких трансформацій, які сприяють досягненню відповідного ступеня адекватності та еквівалентності художнього перекладу, який має естетично вплинути на читача.

У вітчизняному перекладознавстві проблема перекладацьких трансформацій залишається на сучасному етапі однією 3 дискусійних, особливо це стосується визначення самого поняття «перекладацька трансформація», а також кваліфікації основних прийомів трансформацій та створення їхньої несуперечливої типології. У науковій літературі наявні численні тлумачення зазначеного терміна і різноманітні спроби класифікації цього явища. 3 метою визначення перекладацьких трансформацій науковці обирають різні ключові слова, кваліфікуючи їх залежно від своїх наукових поглядів, від розуміння сутності самого процесу перекладу та його моделювання.

У сучасному українському перекладознавстві наявна досить нова класифікація перекладацьких трансформацій, запропонована О. Селівановою, яку вона розробила, спираючись на семантику, синтактику та прагматику, оскільки, на думку дослідниці, переклад $є$ перетворенням мовного продукту однієї семіотичної системи продуктом іншої, орієнтованим на інтерпретанту свого адресата (Селіванова, 2012, с. 458).

Як справедливо зазначає О. Селіванова, «розділити наведені три виміри семіозису як цілісного процесу вкрай важко, адже зміна форми зумовлює здебільшого i зміну смислу, модифікація прагматичного впливу також передбачає зміну форми та змісту повідомлення. Ураховуючи таку нероздільність, перекладацькі трансформації умовно діляться на формальні, формально-змістові, обумовлені специфікою мовних систем оригінального та перекладного текстів, а також контекстуальними та прагматичними 
факторами, та прагматичні, останні $є$ також формально-змістовими» (Селіванова, 2012, с. 458).

У контексті запропонованого дослідження варто зупинитись на визначенні поняття «перекладацької трансформації» українськими дослідниками Т. Кияком, А. Науменком та О. Огуєм, які розглядають перекладацькі трансформації як способи та прийоми перекладу, що «допомагають зберегти риси авторського стилю при адекватному відтворенні змісту оригінального тексту» (Кияк, 2008, с. 532). Справедливою є думка вітчизняних науковців про те, що текст у процесі перекладу зазнає як міжмовних замін (псевдотрансформацій за допомогою формальних i функціональних відповідників), так і певних перекладацьких перетворень (трансформацій), які простежуються на різних мовних рівнях (фонетичному, морфологічному, лексичному, синтаксичному та текстовому).

Потрібно зазначити, що в процесі перекладу художніх творів 3 німецької мови українською виникають значні проблеми, пов'язані 3 відмінностями мовних картин світу та граматичних структур. Саме розбіжності в будові мов, у наборі їхніх граматичних категорій, форм та конструкцій становлять труднощі при перекладі та мають буди враховані при осмисленні тексту. У роботі Т. Кияка, А. Науменка та О. Огуя (Кияк, 2008, с. 532) зазначено, що на морфологічному рівні стандартні морфологічні трансформації знаходять своє вираження в заміні частин мови вихідної одиниці, що $є$ характерним для співвідношення німецької та української мов.

Отже, постає важлива проблема вивчення основних перекладацьких прийомів, які здійснюються на морфологічному рівні в процесі відтворення німецькомовного оригінально тексту українською мовою.

Метою запропонованого дослідження стає вивчення особливостей використання граматичних прийомів замін частин мови під час перекладу збірки Ф. Дюренмата «Лабіринт» українською мовою.

Методи дослідження. У процесі дослідження застосовано трансформаційний метод із метою виявлення усіх можливих приймів трансформацій під час перекладу; порівняльний - для зіставлення структур обох мов та встановлення їхніх спільних і відмінних рис; контекстуальний метод застосовувався з метою продемонструвати можливості вибору прийомів перекладу за умови наявності певного контексту. Використання компонентного аналізу допомогло виявити значення мовних одиниць елементарного змісту (сем), що дало змогу порівняти семний склад одиниць оригіналу та перекладу для виявлення ступеня їхньої відповідності.

Результати дослідження. 3 метою адекватного відтворення змісту художнього тексту перекладачі вдаються до різноманітних прийомів перекладацьких трансформацій, які повністю або частково змінюють структуру речень тексту перекладу. Переклад 3 однієї мови на іншу неможливий без граматичних трансформацій, до яких, першочергово, варто віднести перебудову речення (зміна його структури) та заміни - як синтаксичного, так і морфологічного рівня. Часто використовують також прийом додавання та вилучення одного чи декількох граматичних компонентів.

Варто зазначити, що граматичні трансформації зумовлені різними причинами - як граматичного, так і лексичного характеру, хоча основну роль в першу чергу відіграють граматичні фактори, тобто розходження в структурі мов. 
У процесі перекладу з німецької мови українською з різних причин перекладачу доводиться замінювати одну частину мови іншою. Така заміна може бути викликана прагненням зробити текст перекладу адекватним, уникаючи конструкцій, не властивих мові перекладу.

У процесі порівняльного аналізу збірки Ф. Дюренмата «Лабіринт» та його україномовного перекладу була виявлена значна кількість замін частин мови, спричинена різними факторами. Серед найголовніших - прагнення подолати розбіжності між системою й нормою німецької та української мов.

1. Vor dessen Lektionen wir zitterten, Перед його уроками ми аж тремтіли, denn er war ein bösartiger Prügler, бо той злюка любив нас лупџювати, Klemmer und Haarzieher, der uns щииати й тягати за чуба, а також zwang, einander die Hände zu змушував подавати один одному руку schütteln (Dürrenmatt, 1998, S. 17). $\quad$ (Дюренмат, 2005, c. 12).

Іменники Prügler, Klemmer, Haarzieher, які не мають словникових відповідників, перекладено за допомогою дієслів лупиювати, щзипати, тягти за чуба, що вмотивовано прагненням подолати розбіжності в системі мови оригіналу та мови перекладу і запобігти конструкції, яка не характерна для норми української мови.

2. Nur wenige Züge hatten den Mut, Рідко який потяг, поспішаючи до nicht anzuhalten, brausten vorbei nach далекого Люцерна чи до недалекого dem fernen Luzern, nach dem näheren Берна, зважувався тут не спинитися Bern (Dürrenmatt, 1998, S. 17). $\quad$ (Дюренмат, 2005, с. 13).

У вищезазначеному реченні іменник Mut, який має словниковий відповідник мужність, перекладено дієсловом зважуватися. Такий переклад умотивований тим, що перекладач прагне використовувати словосполучення найбільш уживані в мові перекладу, оскільки словосполучення мати мужність (den Mut haben) в українській мові співвідноситься, зазвичай, 3 живою істотою.

\section{Der Zahntechniker war klein und dick; mit Fragen der Volksgesundheit beschäftigt, ließ er ein Volksbrot verfertigen, bei dem einen das kalte Grausen überkam (Dürrenmatt, 1998, S. 18). \\ Зубний технік був приземкуватий i гладкий, він дбав про народне здоров'я і придумав «народний хліб», жуючи який люди обливалися холодним потом (Дюренмат, 2005, с. 13). \\ У запропонованому реченні вираз mit Fragen beschäftigen, який має переклад займатися питаннями, перекладено дієсловом дбати, що умотивовано прагненням уникнути словотворчих моделей, не характерних для мови перекладу.}

4. Sie las während des Melkens die Bibel, und ich mußte nach dem Abendessen die Hausiere und Vaganten vom Pfarrhaus über die Ebene zwischen dem Dorf und Zäziwil zu ihr in die Hütte führen, wo sie übernachten konnten (Dürrenmatt, 1998, S. 19).
Доячи корову, вона читала Біблію, а я після вечері мав водити від пасторського будинку через рівнину між селом і Цецивілем мандрівних торговців та акторів до іiі хатини на нічліг (Дюренмат, 2005, с. 14). 
Перекладаючи українською мовою прийменникові конструкції, які, відповідно до системи німецької мови, $\epsilon$ досить поширеними, часто використовують прийоми заміни частин мови, що підтверджує наш приклад. Словосполучення während Melkens, яке буквально можна перекласти як nid час доӥння, перекладено дієсловом доїти; німецьке дієслово ӥbernachten зі словниковим відповідником переночувати, перекладено іменником нічліг. Такий переклад вмотивовано прагненням перекладача уникнути неприродності деяких висловів унаслідок невідповідності системи німецької та української мов, що робить зміст речення зрозумілим і відповідним нормі мови перекладу.

5. Meine Eltern gingen den Weg Коли батькові й матері треба було про zwischen den Gräbern auf und ab, wenn щось побалакати, вони походжали sie etwas zu besprechen hatten, und туди-сюди між могилами, а ми із meine Schwestern dich spielten dort сестрою гралися там у піжмурки, Verstecken, oft um das Grabeines частенько ховалися й за могилкою Schwesterchens herum, an dessen нашої сестрички; коли саме вона Geburt und Tod ich mich nicht erinnere, народилась й коли померла, я вже не ich sehe nur noch, denke ich zurück, ein пригадую, пам'ять невиразно зберегла kleines schmiedeeisernes Kreuz mit лише невеличкого кутого хреста 3 einem Emailschildschattenhaft vor mir, емальованою табличкою, а ось яке ім'я aber den Namen, der auf dem Schild на ньому стояло, я вже забув stand, habe ich vergessen (Dürrenmatt, (Дюренмат, 2005, c. 15). 1998, S. 20).

У нашому прикладі дієслово zurückdenken, яке має словниковий відповідник згадувати, пригадувати, перекладено словосполученням пам'ять зберегла. Такий переклад умотивований прагненням використовувати вислови і конструкції, найбільш вживані в українській мові та подолати розбіжності між системою мови оригіналу та перекладу. Необхідно зазначити, що, окрім змін на морфологічному рівні, спостерігаємо використання прийому конверсійної заміни, оскільки граматичні прийоми, які перекладач застосовує 3 метою наближення до норми рідної, призводять інколи до модифікації мовних одиниць на лексичному рівні, не змінюючи при цьому лексичного значення.

\begin{tabular}{|l|l|}
\hline 6. Nichtnur mit dem Tod waren wir & Ми не тільки добре знали, що таке \\
vertraut, auch mit dem Töten & $\begin{array}{l}\text { смерть, а й уміли вбивати (Дюренмат, } \\
\text { (Dürrenmatt, 1998, S. 21). }\end{array}$
\end{tabular}

У запропонованому реченні прийменникова конструкція mit dem Töten перекладена дієсловом вбивати. Такий переклад умотивовано прагненням уникнути нелогічності вираження у мові перекладу та подолати розбіжності між нормою мови оригіналу та перекладу.

7. Gut und Böse waren festgesetzt, man stand in einem ständigen Examen, für jeden Tag gab es gleichsam Noten, und darum war die Schule auch so bitter: sie setze das himmlische System auf Erden fort, und für die Kinder waren die Erwachsenen Halbgötter (Dürrenmatt, 1998, S. 29).

Межі добра і зла були чітко окреслені, людям доводилося постійно тримати іспит, кожен вчинок мав немовби свої оцінки, і через те й школа викликала стільки гіркоти: вона була продовженням небесної системи на землі, а дорослі для дітей були напівбогами (Дюренмат, 2005, с. 22). 
У наведеному реченні прикметник bitter перекладено іменником гіркота, що вмотивовано прагненням перекладача використовувати вислови та слова, які притаманні саме мові перекладу, долаючи розбіжності між нормою мови оригіналу та перекладу.

8. Man war dem Glauben ausgeliefert, Доводилося хоч-не-хоч вірити, вірити, schutzlos und nackt (Dürrenmatt, 1998, S. 29). стоячи перед ним беззахисно, в чому мати спородила (Дюренмат, 2005, c. 22).

У запропонованому реченні словосполучення dem Glauben ausgeliefert sein, яке має словниковий відповідник віддаватися вірі, перекладено нейтральним дієсловом «вірити», що підтверджує наявність стилістичної нейтралізації; а прикметники schutzlos und nackt - за допомогою описового перекладу, унаслідок чого текст перекладу стає навпаки емоційніше забарвленим ніж оригінал. Отже, одночасне використання стилістичної нейтралізації та компенсації підтверджує наявність стилістичної компенсації, використання якої викликано прагненням перекладача відтворити тональність оригінального тексту та створити подібне емоційне враження, яке отримують читачі оригінального тексту.

9. Es aufzutreiben war schon ein Роздобувати їх стало в нас справжнім Kunststück, setzte Lügen, Stehlen und мистецтвом: треба було вміти брехати, Pumpen voraus (Dürrenmatt, 1998, красти й позичати (Дюренмат, 2005, S. 49). c. 38).

Переклад іменників Lügen, Stehlen und Puтреп за допомогою дієслів брехати, красти, позичати вмотивовано прагненням подолати розбіжності в системі мови оригіналу та мови перекладу і запобігти конструкції, яка не характерна для української мови.

10. In welchen Räumen fürchtete er $\mathrm{У}$ яких кімнатах і залах відчував страх sich und wovor? (Dürrenmatt, 1998, і перед чим? (Дюренмат, 2005, c. 56) S. 70)

Дієслово fürchten, який має словниковий відповідник боятися, перекладено словосполученням, до складу якого належить іменник відчувати cтрах, що вмотивовано прагненням забарвити ситуацію для більш вдалого відтворення емоційного стану героя.

Висновки. Отже, здійснивши порівняльний аналіз збірки швейцарського письменника Ф. Дюренмата «Лабіринт» та його перекладу, зробленого відомим українським перекладачем О. Логвиненком, ми дійшли висновку, що перекладачем з метою створення адекватного тексту, а саме досягнення емоційного впливу, до якого прагне текст-джерело, було використано значну кількість граматичних замін. Підсумовуючи, потрібно зазначити, що основними мотивами застосування граматичних замін частин мови $\epsilon$ переважно прагнення подолати розбіжності між системою та нормою мови оригіналу і перекладу, уникнути буквалізмів, неприродності деяких зворотів та використовувати граматичні конструкції, які відповідають нормі української мови. 


\section{Бібліографія}

Андрієнко, Т. П. (2016). Стратегії і тактики перекладу: когнітивно-дискурсивний аспект (на матеріалі художнього перекладу з англійської мови на українську та російську): монографія. К.: Видавничий дім Дмитра Бураго.

Бев3, Н. В. (2010). Переклад як культурний феномен: герменевтико-комунікативний аспект: автореф. дис. на здобуття наук. ступеня канд. філос. наук: спец. 09.00.04 «Філософська антропологія, філософія культури». Харків.

Демецька, В. В. (2006). Теорія адаптації: крос-культурні та перекладознавчі проблеми: монографія. Херсон: МП «Норд».

Дюренмат, Ф. (2005). Лабіринт: Тексти I-III: Зимова війна в Тибеті; Місячне затемнення; Бунтар. / 3 нім. пер. О. Логвиненко. К.: Юніверс.

Зорівчак, Р. П. (2007). Український художній переклад як націє творчий чинник. Зарубіжна література. Квіт. (Чис. 14). С. 1-5.

Іваницька, М. (2015). Особистість перекладача в українсько-німецьких літературних взаєминах: монографія. Чернівці: Книги-XXI.

Коломієць, Л. В. (2004). Концептуально-методологічні засади сучасного українського поетичного перекладу: монографія. К.: Вид. полігр. центр «Київський університет».

Кияк, Т. Р. (2008). Науменко А. М., Огуй О. Д. Перекладознавство (німецькоукраїнський напрям): підручник. К.: Видавничо-поліграфічний центр «Київський університет».

Лановик, М. Б. (2006). Проблеми художнього перекладу як предмет літературознавчої рефлексії: автореф. дис. на здобуття наукового ступеня доктора філол. наук: спец. 10.01.06 «Теорія літератури». К.

Ребрій, О. В. (2012). Сучасні концепції творчості у перекладі: монографія. Х.: ХНУ імені В. Н. Каразіна.

Селіванова, О. О. (2012). Світ свідомості в мові. Мир сознания в языке. Монографічне видання. Черкаси: Ю. Чабаненко.

Стріха, М. (2006). Український художній переклад: між літературою і націєтворенням. К.: Факт-Наш час.

Чередниченко, О. І. (2008). Український переклад: з минулого у сьогодення. Од слова путь верстаючи ц̌ до слова...: зб. на пошану Р. П. Зорівчак, д-ра філол. наук, проф., засл. працівника освіти України / ред. кол.: О. І. Чередниченко [та ін.]. Львів: Вид. центр ЛНУ ім. І. Франка, С. 21-31.

Dürrenmatt Friedrich. (1998). Labyrinth: Stoffe I-III: Der Winterkrieg in Tibet; Mondfinsternis; Der Rebell. Zürich: Diogenes Verlag.

\section{References}

Andriyenko T. P. (2016). Strategiyi i takty`ky` perekladu: kognity`vno-dy`skursy`vny`j aspekt (na materiali xudozhn`ogo perekladu $\mathrm{z}$ anglijs`koyi movy` na ukrayins`ku ta rosijs`ku): monografiya. K.: Vy`davny`chy j dim Dmy`tra Burago.

Bevz N. V. (2010). Pereklad yak kul`turny`j fenomen: germenevty`ko-komunikaty`vny`j aspekt: avtoref. dy`s. na zdobuttya nauk. stupenya kand. filos. nauk: specz. 09.00.04 «Filosofs`ka antropologiya, filosofiya kul`tury`». Xarkiv.

Demecz ka V. V. (2006). Teoriya adaptaciyi: kros-kul`turni ta perekladoznavchi problemy`: monografiya . Xerson: MP «Nord».

Dyurenmat F. (2005). Labiry`nt: Teksty` I-III: Zy`mova vijna v Ty`beti; Misyachne zatemnennya; Buntar. / Z nim. per. O. Logvy`nenko. K.: Yunivers.

Zorivchak R. P. (2007). Ukrayins`ky`j xudozhnij pereklad yak naciye tvorchy`j chy`nny`k. Zarubizhna literatura. Kvit. (Chy`s. 14). S. 1-5.

Ivany`cz`ka M. (2015). Osoby`stist` perekladacha v ukrayins`ko-nimecz`ky`x literaturny`x vzayemy`nax: monografiya. Chernivci: Kny`gy` - XXI.

Kolomiyecz` L. V. (2004). Konceptual`no-metodologichni zasady` suchasnogo ukrayins `kogo poety`chnogo perekladu: monografiya. K.: Vy`d. poligr. centr «Ky`yivs`ky`j universy`tet». 
Ky`yak T. R. (2008). Naumenko A. M., Oguj O. D. Perekladoznavstvo (nimecz`koukrayins`ky`j napryam): pidruchny`k. K.: Vy`davny`cho-poligrafichny`j centr «Ky`yivs`ky`j universy`tet».

Lanovy`k M. B. (2006). Problemy`xudozhn`ogo perekladu yak predmet literaturoznavchoyi refleksiyi: avtoref. dy`s. na zdobuttya naukovogo stupenya doktora filol. nauk: specz. 10.01 .06 «Teoriya literatury`». K.

Rebrij O. V. (2012). Suchasni koncepciyi tvorchosti u perekladi: monografiya. X.: XNU imeni V. N. Karazina.

Selivanova O. O. (2012). Svit svidomosti v movi. My`r soznany`ya v yazyke. Monografichne vy`dannya. - Cherkasy`: Yu. Chabanenko.

Strixa M. (2006). Ukrayins`ky`j xudozhnij pereklad: mizh literaturoyu i naciyetvorennyam. K.: Fakt-Nash chas.

Cheredny`chenko O. I. (2008). Ukrayins`ky`j pereklad: z my`nulogo u s`ogodennya. Od slova put verstayuchy`j do slova.... zb. na poshanu R. P. Zorivchak, d-ra filol. nauk, prof., zasl. pracivny`ka osvity`Ukrayiny`/ red. kol.: O. I. Cheredny`chenko [ta in.]. L`viv: Vyd. centr LNU im. I. Franka. S. 21-31.

Dürrenmatt Friedrich (1998). Labyrinth: Stoffe I-III: Der Winterkrieg in Tibet; Mondfinsternis; Der Rebell. Zürich: Diogenes Verlag.

\section{Резюме}

\section{Кучер Зоя}

\section{ПРОБЛЕМА ВИКОРИСТАННЯ ПЕРЕКЛАДАЦЬКИХ ТРАНСФОРМАЦЙ В ПРОЦЕСІ ПЕРЕКЛАДУ ХУДОЖНЬОГО ТЕКСТУ}

Постановка проблеми. Актуальність запропонованої статті пов'язана зі станом сучасних вітчизняних досліджень у галузі перекладознавства, що характеризуються значним інтересом до проблеми художнього перекладу як особливого виду перекладацької діяльності, а саме вивчення способів та прийомів адекватного відтворення оригінального тексту.

Мета статті. Метою запропонованого дослідження є вивчення особливостей використання прийомів граматичних замін частин мови в процесі перекладу художнього твору Ф. Дюренмата «Лабіринт» українською мовою.

Методи дослідження. У процесі дослідження було застосовано трансформаційний метод 3 метою виявлення усіх можливих приймів трансформацій під час перекладу; порівняльний - для зіставлення структур обох мов та встановлення їхніх спільних і відмінних рис; контекстуальний метод застосовувався з метою продемонструвати можливості вибору прийомів перекладу за умови наявності певного контексту. Використання компонентного аналізу допомогло виявити значення мовних одиниць елементарного змісту (сем), що дозволило порівняти семний склад одиниць оригіналу та перекладу для виявлення ступеня їхньої відповідності.

Основні результати дослідження. 3 метою адекватного відтворення змісту художнього тексту перекладачі вдаються до різноманітних прийомів перекладацьких трансформацій, які повністю або частково змінюють структуру речень тексту перекладу. Переклад 3 однісї мови на іншу неможливий без граматичних трансформацій, до яких, у першу чергу, варто віднести перебудову речення (зміна його структури) та заміни - як синтаксичного, так і морфологічного порядку. 
Висновки та перспективи. Здійснивши порівняльний аналіз збірки швейцарського письменника Ф. Дюренмата «Лабіринт» та українського перекладу, зробленого О. Логвиненком, приходимо до висновку, що перекладачем 3 метою створення адекватного тексту, а саме досягнення емоційного впливу, до якого прагне текст-джерело, було використано значну кількість граматичних замін. Основними мотивами застосування граматичних замін частин мови переважно є прагнення подолати розбіжності між системою та нормою мови оригіналу та перекладу, уникнути буквалізмів, неприродності деяких зворотів та використовувати граматичні конструкції, відповідні нормі української мови.

Ключові слова: перекладацька трансформація, граматична заміна, заміна частин мови, адекватний переклад, мотиви використання перекладацьких трансформацій.

\section{Abstract \\ Kucher Zoja \\ THE PROBLEM OF EMPLOYING TRANSLATION TRANSFORMATIONS WHILE TRANSLATING AN ART WORK}

Problem statement. The topicality of the proposed article is related to the state of modern research in our country in the field of translation studies characterized by a considerable interest in the field of artistic translation as a special type of translation activity, namely, the study of methods and techniques for the adequate reproduction of the original text.

Purpose of the article. The purpose of the proposed research is the study of peculiar use of grammatical substitutions of parts of speech in the process of translation of the literary work "Labyrinth" by F. Durrenmatt into Ukrainian

Research methods. In the research process a number of methods were applied. A transformation method was used to study all possible transformation techniques during translation. A comparative method was used for the comparison of the structures of both languages and the establishment of their common and distinctive features. A contextual method was used to demonstrate the possibilities of choosing the translation methods if there is a certain context. The use of the component analysis enabled to reveal the values of the linguistic units of elemental content (seme), which allowed comparing the seminal composition of the original units and the translation to determine the degree of their correspondence.

Main results of the study. In order to reproduce the content of the artistic text adequately, the translator makes use of various techniques of translation transformations that completely or partially alter the structure of the sentences of the text of the translation. Translation from one language into another is impossible without grammatical transformations which, in the first place, should include the reconstruction of the sentence (change in its structure) and the replacement of both syntactic and morphological order.

Conclusions and perspectives. Based on a comparative analysis of the collection "The Labyrinth" by the Swiss writer F. Durrenmatt, and the Ukrainian translation by O. Logvynenko, we conclude that the interpreter used a significant number of grammatical substitutions. The main purpose of which was the creation of an adequate text, namely the achievement of the emotional influence, which the text 
source seeks to. The main reasons for using grammatical substitutions of the parts of speech is mainly the desire to overcome the differences between the system and the norm of the original language and the translation, to avoid literalisms as well as the unnatural expressions, and to use the grammatical constructions, corresponding to the norm of the Ukrainian language.

Keywords: translation transformation, grammatical replacement, replacement of parts of speech, adequate translation, motives for the use of translation transformations.

\section{Відомості про автора}

Кучер Зоя Іванівна, кандидат філологічних наук, дочент, завідувач кафедри романогерманської філологї та перекладу Черкаського державного технологічного університету, м. Черкаси, Україна, е-таil: zoya.kucher18@gmail.com

Kucher Zoya, Ph.D. in Philology, Associate Professor, the Head of Department of Romance and German Philology and Translation of Cherkasy State Technological University, Cherkasy, Ukraine,e-mail: zoya.kucher18@gmail.com

ORCID 0000-0002-6055-4086

Надійшла до редакції 02 квітня 2019 року Прийнято до друку 15 квітня 2019 року 